\title{
Gotong Royong in Organization
}

\author{
Nicholas Simarmata ${ }^{1}$, Kwartarini Wahyu Yuniarti ${ }^{2}$, Bagus Riyono ${ }^{3}$ and Bhina Patria ${ }^{4}$ \\ ${ }^{1}$ Psychology Study Program, Medical Faculty, Udayana University, Bali, Indonesia \\ and Psychology Faculty, Gadjah Mada University, Yogyakarta, Indonesia \\ ${ }^{2,3,4}$ Psychology Faculty, Gadjah Mada University, Yogyakarta, Indonesia \\ nicholas@unud.ac.id
}

\begin{abstract}
Gotong royong is an original term from Indonesia which means cooperation among society members. Gotong royong is the culture value of the Nusantara (before the establishment of the Indonesian country) since the Neolithic era from $6000 \mathrm{BC}$, the core of Pancasila (the ideology of the Indonesian country), and plays a role in the government, public and private sectors. There have been many studies of gotong royong in the government and society sectors. But it is still rarely done in the private sector, especially in organizations. This study is a literature study by using various references from books and journals, both printed and online. The theory that is used to study gotong royong in this study is the Social Psychology theories. Those are need-to-belong theory, interdependence theory, communal theory, cooperation theory, and collectivism theory. The results of this study are expected to be the basis for further empirical studies so that later it can obtain a gotong royong picture in organizations both theoretically and empirically.
\end{abstract}

Keywords: Gotong royong, Culture value, Organization, Interdependence theory, Communal sharing

\section{Introduction}

Indonesia is gotong royong, and vice versa. Because Indonesia and gotong royong are two things interrelated, one unity and cannot be separated. The first thing that underlies interrelation between Indonesia and gotong royong is Indonesian society is social being and basically human being is social creature [1]. Human tends to establish relationship with other human that ultimately forms society. Relationship is not just an interaction, but leads to realizing the life welfare by doing the work together. This is known in Indonesia as gotong royong [2]. Hence, human, in this case is Indonesian society, is social being who cannot live alone and must cooperate to achieve common goal by gotong royong [2][3] The second thing that underlies interrelation between Indonesia and Gotong royong is the diversity of Indonesian society. Indonesia consists of 1340 ethnics, 1128 tribes and 1211 local languages [4][5][6]. The diversity in Nusantara (Indonesia) has been around 2.5 million years ago and this is a strength because there is a care and share tradition that is Gotong royong [6]. Hence, it shows Gotong royong can unite the diversity of Indonesian society [6].

Article history:

Received (February 17, 2020), Review Result (March 21, 2020), Accepted (April 29, 2020) 
The third thing that underlies interrelation between Indonesia and Gotong royong is collectivism and communalism on Indonesian society. Because communalism and collectivism is the characteristic of Indonesian society [7][8]. Therefore, Gotong royong is a tradition from communalism in a collectively work [9]. The reason that strengthen the three things that underlie interrelation between Indonesia and Gotong royong is Gotong royong has been known by Nusantara (before the establishment of the Indonesian country) society when the removal of Menhir stones (Neolithic era - starting 6000 BC) with a large tonnage for ancestor worship in Nias island [10]. Thus, Gotong royong is important and relevant for Indonesia because Gotong royong is not only applied in the past, but also for the present and the future of Indonesia [11]. This means that gotong royong becomes the basis and guidance for the behavior of Indonesian society under the changing times. The interrelation between Indonesia and Gotong royong is also seen in the role of Gotong royong in society, government and private sector. In society sector, Gotong royong is a life-practice of mutual help voluntarily that is the society comes to help based on sincerity to engage, participate and togetherness [12]. In custom works in Indonesia, there are many terms for Gotong royong but they have the same relative meaning because Gotong royong is not only belonged to certain ethnic groups in Indonesia [13]. In government sector, Gotong royong has a role as a basic element in national construction in Indonesian history since Independence Day [6]. M. Nasroen (the pioneer of Indonesia philosophical study) stated that Gotong royong is included the foundation of Indonesia's philosophy so that Gotong royong is used as a survival strategy for the society and Indonesia government [14]. Hence, the Indonesian government said that Indonesia has Gotong royong culture that is cooperative culture, mutual help and mutual support. Beside in society and government sector, Gotong royong also has a role in the private sector. Joko Widodo (the 7th and 8th President of the Republic of Indonesia) said that Gotong royong is needed among the government, the society and the private sector. The private sector in this context means organization. Gotong royong in the organization includes the Indonesian value that is compatible with 20th century skill because Gotong royong among work units are a necessity. There is cohesiveness in Gotong royong so that people are encouraged to become psychologically and emotionally interrelated with each other. It reflects a strong emphasis on compactness and interdependence among organization members. Gotong royong is the characteristic of Indonesian workers. Gotong royong is also a positive work attitude because it makes compact and effective teamwork [15]. By working towards the realization of modern Gotong royong, the life of Indonesian nation becomes stronger. The researchers conducted a literature study to investigate the research development on gotong royong from various studies and contexts. The result from literature study shows that there are some research on gotong royong based on various contexts. Those contexts are the society, society and government, school finance, government, children game technology, education game and politic [16]. Gotong royong has also been researched from several sciences. Those sciences are social sciences, anthropology, philosophy, civic education, law and public health, language, sociology education, economy and business, national defend, history, technical information, education, psychology, social and politic. From the above explanation, it is understood that Gotong royong is important for Indonesia. It is seen empirically in the form of Gotong royong role in society and government. It is also seen theoretically in the form of researches that have been done in several contexts and with several sciences.

Hence, it needs a study of Gotong royong by psychology science in the organization context in order to add and complete the variations of Gotong royong study from other science and context so that it can gain a comprehensive understanding of Gotong royong. 
The rest of this paper is organized as follow: Section 2 describes the literature review. And theoretical background. Section 3 describes the proposed method. Finally, Section 4concludes this work.

\section{Literature review}

\subsection{Gotong royong}

Gotong royong comes from a combination of two words from the Javanese ethnic that is gotong which means to lift and royong means together. Hence, Gotong royong means lifting something together [17]. Gotong royong belongs to Indonesia, the term from Indonesia ,Indonesian nationalistic phrase, Indonesian indigenous character, Indonesian life base, main characteristic of Indonesia, the basic culture of Indonesia, Indonesian national culture, Indonesian cultural philosophy, Indonesian life pattern, Indonesian culture attitude, Indonesian character, Indonesian fundamental value, Indonesian society value, modern value of Indonesian version, noble value relating to Indonesian local wisdom, Indonesian cultural value, Indonesian social wisdom component, Indonesian solidarity basis, Indonesian society principle, Indonesian society idea about cooperation activity, important characteristic of Indonesian society, common belief of Indonesian society, the form of social intelligence from Indonesian society, the behavior, ideal, norm, rule and lifeview of Indonesian society, strength core of Indonesian society culture, Indonesian typical characteristic, social relation of Indonesian society and Indonesia trait that is hereditary and until now still well maintained [18].

\subsection{Need-to-Belong theory}

The core idea of the need-to-belong is that people have a fundamental, strong, and pervasive motivation to form and maintain at least a certain minimum number of social relationships. The drive to connect with others was more than a mere desire. The central aspects of the need-to-belong; first, the person wants a framework of mutual concern and caring that extends into past and future. Second, the person wants a series of non-negative interactions. The need-to-belong is not satisfied by any amount of social interaction without the bond. People must desire at least a certain minimum amount of social connection, and to some extent these bonds could substitute for each other. They would most like to keep the bonds they have, but if they lose one relationship, having others could cushion the blow and satisfy some of the same need. Humans evolved to be social beings, and so they needed to be connected to each other. The goal of need-to-belong theory is to understand people, to foster an inclusive society and to enable people to find ways to feel connected with others. Implication of need-to-belong theory for societies and organizations is to ensure that all, including those at the bottom, are encouraged to feel accepted and included. The theory of the need-to-belong has evolved from a simple insight about desiring togetherness into a large complex of interrelated ideas. It seems vital for psychology to rediscover an appreciation for what happens between people. What happens inside them is important also, but often it happens because of what happens between them. Inner process serves interpersonal functions. Need-to-belong theory is a fundamental and powerful fact about human nature [19].

\subsection{Communal theory}


Communal norm organizes relation with the principle that benefitis given without expecting reward, but it based on caring for the other needs and a sense of responsibility for the other well-being [20]. The receiver should not feel obligated or indebted to provide reciprocal benefit. In the perspective of the communal theory, the working of communal norm in a relation is related to the level of understanding of mutuality and perspective-taking. A person who has an understanding toward mutuality and has the ability to understand other people's point of view will improve the communal orientation, that is the tendency to follow the norm in communal relation.

Communal relation has a basic principle in the form of unity moral value or unity that "instilling obligation" in each person will provide assistance with orientation on the achievement of the other welfare, without hoping there will be a reward [21]. The high and low of the communal orientation determines the level of one's communal strength. The higher the communal power, the greater the responsibility for the other welfare. The willingness and availability to fulfill the need and attainment of the other welfare will increase and take precedence. Communal relation does not mean unauthorized relation (unselfish relation). A communal orientation in one's self also there is a hope that other will also follow communal norm when building relationship and interacting. The help or benefit giver (donor) actually hopes that other or receiver (recipient) will have the same communal motivation as him/herself and be willing to give help to others. The giving of assistance or benefit in communal relation is motivated by a sense of care for the needs and responsibilities of the other welfare. Goffman calls it as "when someone feels called to give benefit". Hence, in communal relation, benefit is given as support for the other good (the giver and the receiver do not feel there is a "debt" that it has to be "paid") and people are tend to help and responsible toward the other situation [22].

\subsection{Interdependence theory}

Interdependence theory explains the conceptualization of structure and process that take place in interpersonal relation, which was proposed by Thibaut \& Kelley in Bang [23] to explain the emergence of interdependence. The study of relation is considered as important as the study of the individual that is involved in that relation. Interdependence theory is built on four basic assumptions. First, structure principle from situation. Understanding the situation of interdependence is an important part to be able to understand the psychological process of individual that is involved in a relation. Second, transformation principle. The transformation process occurs when individual begin to consider that the behavior of him/herself has consequence of each other that arise in the near future or long-term effect. Transformation is a psychological process involving affection, cognition, and motivation that is influenced by the interaction purpose. Third, interaction principle. Interaction in interdependence is a function from two persons (Symbols A and B) and object or resource that exist in one situation (Symbol S). Situation in interaction can activate people affection, cognition, and motivation and affect mutual respond and pattern that are formed. Fourth, adaptation principle. Social interaction that is repeated can create adaptation that can make relation more stable and facilitate the transformation process. Adaptation concerns individual orientation differences (A and B), the orientation role towards specific relation and social norm that is socialized through culture that apply to certain society. In Interdependence theory, interchangeable objects are not always concrete, but they can also be symbolic [24].

\subsection{Cooperation theory}


This theory was originally developed by Galata in [25] and much described by mark [26]. The cooperative process encourages greater group productivity, more favorable interpersonal relation, better psychological health and higher self-esteem. Cooperation encourages and is encouraged by the shared feelings in belief and attitude, readiness to help, openness in communication, trust and cordiality, sensitivity to common interest, orientation towards increasing joint strength. If someone has systematic knowledge about the process effect that is cooperative, then he/she has systematic knowledge of the condition that usually leads to that process. The early theory of Deutsch of cooperation is the theory about the effect of a cooperative process. This theory explains the condition that gives rise process that is cooperative.

\subsection{Collectivism theory}

The antecedents of collectivism can be found in the ecology, family structure, wealth distribution, demography, history, cultural diffusion, and situational conditions. The consequences of collectivism include differences in attention, attribution, cognition, emotion, motivation, self-definitions, values, language use, and communication, as well as other kinds of social and organizational behavior. Applications of collectivism include improvements in conflict resolution, health, international relations, and cross-cultural training. Collectivism is society in which people from birth onward are throughout people's lifetime continue to protect them in exchange for unquestioning loyalty. Collectivism is family integrity and interdependence with sociability.

In collectivistic cultures, the self is interdependent with some group. The goals of the groups have priority over individual group and in-group and individual goals are usually the same. Norms, obligations, and duties guide behavior. Communal relations are most frequent and individuals stays in unpleasant groups or relationships. Within organizational context, a lack of understanding of cultural differences can translate into failed mergers and ventures, premature expatriate return and turnover, and organizational conflict. Understanding key cultural differences related to collectivism is a key business imperative.

\section{Methodology}

This study is a literature study. The literature was obtained from articles, books, or journals in a form of either printed or online. On online form, researchers type "gotong royong" as keyword when using Google Scholar and several Journal Websites that are subscribed by Gadjah Mada University.

\section{Conclusion}

The conclusion that can be drawn about Gotong royong in the organization context according to the study of social psychology theories is as follows. Need-to-Belong Theory said that the individual has a fundamental and powerful motivation for shaping and maintaining social relation because the fundamental fact from human existence is not conflict but cooperation. Hence, gotong royong at organization is based on a strong motivation to have social relation because by working together the burden can be borne together so that common goal can be achieved. The relation within gotong royong in the organization is getting tighter because of mutuality (every individual needs each other) and trust (each individual put trust). Interdependence theory explained that goal is determined by individual interaction, or in other words, pattern of interaction determine goal. Hence, Gotong royong in the organization is formed because individual interact with each other in the context of 
cooperation to achieve common goal. This means that every individual knows and is aware that they must do gotong royong because by that way then the burden, task, responsibility is handled and lighter because it is shared together. Communal theory suggests that benefit is given as support for the other good (the giver and the receiver do not feel there is a "debt" to be "paid"). Hence, there is gotong royong in the organization because individuals "complement each other" to achieve common goal, help each other and care for each other. By doing so, it actually helps the individual him/herself because the end result of the common goal is the contribution of each individual. The Cooperation theory said that the basic psychological orientation of cooperation implies a positive attitude that is "We" (inclusive) for each other and "We" (inclusive) mutually benefiting each other. Therefore, gotong royong in the organization of course very relevant and it requires cooperation among individuals. The purpose of relation among individuals when they do gotong royong in the organization are to achieve the common goal by cooperation. Collectivism theory mentioned that collectivism is related to society where individual from birth onwards is integrated into powerful and cohesive group that throughout his/her lifetime continue to protect him/her in return for unquestionable loyalty. The existence of gotong royong in the organization because individual join into the group so that there is relation among individuals who aim to perform and solve something together with uphold the group interest. From the study that has been described above then this study can be developed as a basis for further empirical studies so that it can obtain a picture of gotong royong in the organization theoretically and empirically.

\section{Acknowledgement}

This research is fully supported by Gadjah Mada University Grant.

\section{References}

[1] Dewantara A., "gotong-royong” as Indonesian Philosphy in Max Scheler Perspectives, (2019)

[2] Slikkerveer L. J., "Gotong royong: An indigenous institution of communality and mutual assistance in Indonesia,” In Integrated Community-Managed Development, pp.307-320, Springer, Cham, (2019)

[3] Iqbal M. N. M. “Advancing social capital through participatory approaches," EMARA Indonesian Journal of Architecture, vol.4, no.1, pp.1-12, (2018)

[4] Sholihah A. B. and Athas S. I. A., "Analysis of social sustainability models: toward more sustainable indonesian cities," Advanced Science Letters, vol.24, no 12, pp.9219-9222, (2018)

[5] Naim M. and Hindmarsh R., "Traditional-contemporary' community engagement approaches for effective local climate change adaptation in Indonesia, Jurnal Ecolab, vol.13, no.1, pp.39-59, (2019)

[6] Hermawan M. S. and Loo M. K., "The construction of kekeluargaan as an Indonesia's organizational culture," Jurnal Humaniora, vol.31, no.1, pp.1-13, (2019)

[7] Abdullah I., "Communalism shattered: Thirty years of conflict experiences in the province of Aceh," Indonesia. Anthropological Notebooks, vol.24, no.1, (2018)

[8] Triandis H. C., "Individualism and collectivism," Routledge, (2018)

[9] Sullivan G. B., "Rethinking resilience, culture and disasters: implications and applications In Indonesia," Disaster Risk Reduction in Indonesia: Environmental, Social and Cultural Aspects, pp.186, (2018)

[10] Sembiring S. A. B., "Agricultural practice and social change in Berastagi area," In IOP Conference Series: Earth and Environmental Science, vol.126, no.1, pp.012096, IOP Publishing, (2018)

[11] Wahyuni S., Junaidi J., and Mustangin M., "Integration of gotong royong indonesian culture in assessing students' social attitudes," In 2nd Workshop on Language, Literature and Society for Education, European Alliance for Innovation (EAI), (2018) 
[12] Gading I. K., Widiana I. W., Jampel I. N., and Parmiti D. P., "Effectiveness of self-modification program in smoking reduction," The Social Sciences, vol.13, no.1, pp.63-69, (2018)

[13] Zulfadrim Z., Toyoda Y., and Kanegae H., "The implementation of local wisdom in reducing natural disaster risk: a case study from West Sumatera," In IOP Conference Series: Earth and Environmental Science vol.106, no.1, pp.012008, IOP Publishing, (2018)

[14] Pheeney C. E., "Pancasila culture and social justice," In Research for Social Justice: Proceedings of the International Seminar on Research for Social Justice (ISRISJ 2018), October 30, 2018, Bandung, Indonesia pp.157, Routledge, (2019)

[15] Mustam B. and Daniel E. S., "Informal and formal environmental education infusion: actions of malaysian teachers and parents among students in a Polluted Area," MOJES: Malaysian Online Journal of Educational Sciences, vol.4, no.1, pp.9-20, (2018)

[16] Saltman K. J., "The politics of education: A critical introduction. Routledge,” (2018)

[17] Robinson G., "The dark side of paradise: Political violence in Bali.," Cornell University Press, (2018)

[18] Kawangung Y., "Religious moderation discourse in plurality of social harmony in Indonesia," International journal of social sciences and humanities, vol.3, no.1, pp.160-170, (2019)

[19] Baxter D. E. and Pelletier L. G., "Is nature relatedness a basic human psychological need? A critical examination of the extant literature," Canadian Psychology/psychologie canadienne, vol.60, no.1, pp.21, (2019)

[20] Peters B. J., Reis H. T., and Gable, S. L., "Making the good even better: A review and theoretical model of interpersonal capitalization," Social and Personality Psychology Compass, vol.12, no.7, e12407, (2018)

[21] Lasch C., "The culture of narcissism: American life in an age of diminishing expectations," WW Norton \& Company, (2018)

[22] George V. "Social security and society," Routledge, (2018)

[23] Bang H., Bravo G. A., Mello Figuerôa K., and Mezzadri F. M., "The impact of volunteer experience at sport mega - events on intention to continue volunteering: Multigroup path analysis," Journal of community psychology, vol.47, no.4, pp.727-742, (2019)

[24] Hatch M. J., "Organization theory: Modern, symbolic, and postmodern perspectives,” Oxford university press, (2018)

[25] Galata A. A., Anogiannakis S. D., and Theodorou D. N., "Thermodynamic analysis of Lennard-Jones binary mixtures using Kirkwood-Buff theory," Fluid Phase Equilibria, vol.470, pp.25-37, (2018)

[26] Mark N. P., "Status organizes cooperation: an evolutionary theory of status and social order," American Journal of Sociology, vol.123, no.6, pp.1601-1634, (2018) 
This page is empty by intention.

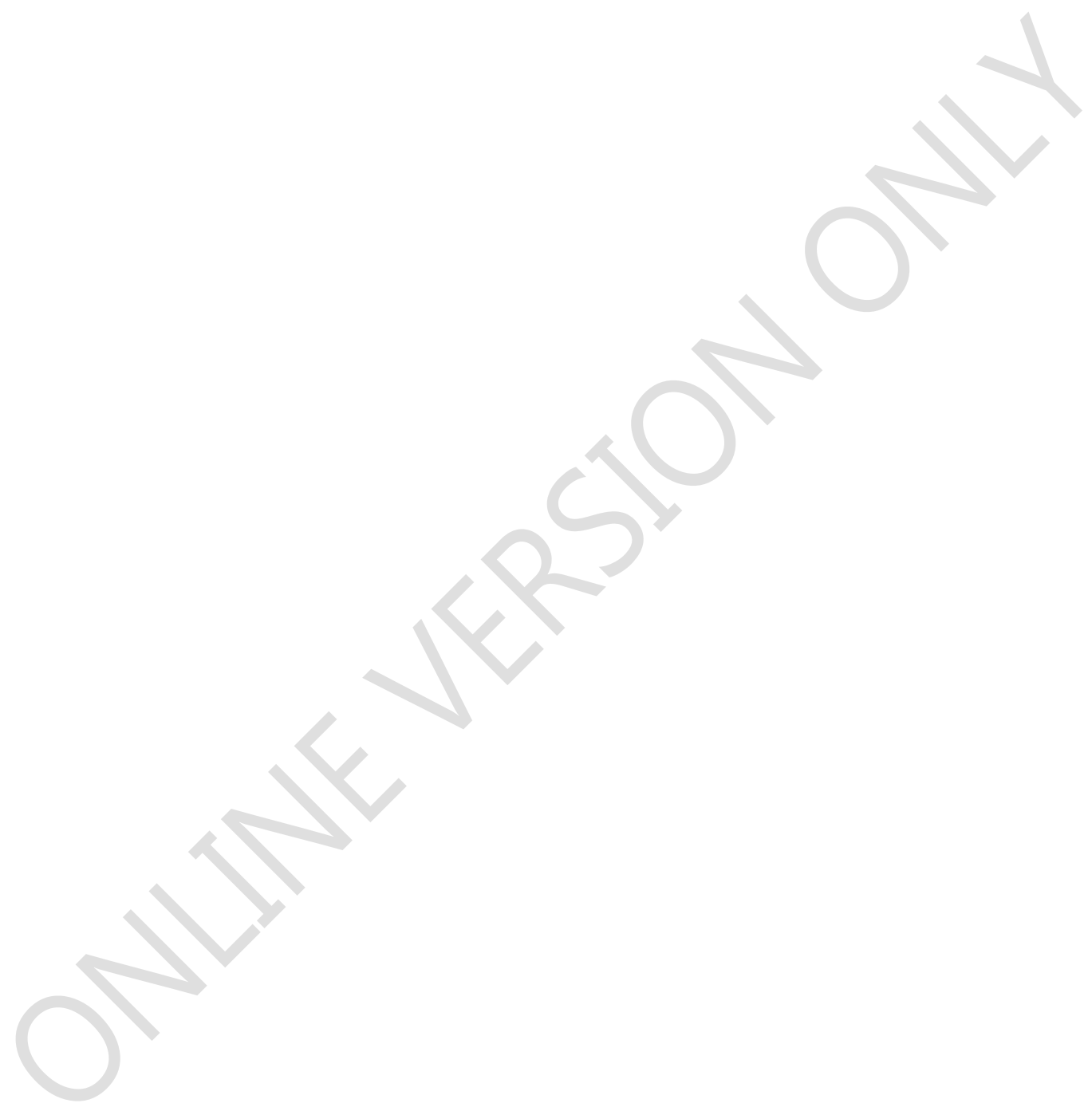

